\title{
Korelasi Tipe Pemain Dengan Pengukuran Usability Pada Game Freemium
}

\author{
Correlation of Player Type with Usability Measurement in Freemium Games \\ Rizky \\ Program Studi Teknologi Informasi, Universitas AMIKOM Yogyakarta \\ E-mail: samrizky@amikom.ac.id
}

\begin{abstract}
Abstrak
Game merupakan kategori terpopuler di Play Store dan App Store, matangnya industri game sudah terbentuk sejak puluhan tahun lalu dari zaman konsol. Value Chain game di zaman mobile mengalami perubahan yang signifikan, terutama di sisi distribution channel yang memotong banyak proses. Namun, disayangkan developer banyak hanya berfokus pada proses penciptaan game, tanpa mempersiapkan strategi monetising yang baik, salah satunya adalah model Freemium dan Premium. Untuk itu diperlukan studi lebih lanjut tentang tipe tipe pemain yang akan berhubungan dengan keputusan pembelian game. Penelitian ini bertujuan untuk mengetahui korelasi tipe pemain terhadap pengujian usability dan dapat digunakan sebagai salah satu acuan dalam penentuan model bisnis game bagi para developer. Metode yang digunakan yaitu analisis deskriptif persentase. yang disesuaikan dengan kondisi pemain. Hasil penelitian ini menunjukkan bahwa tipe pemain yang terdiri dari empat jenis pemain memiliki pengaruh yang tidak signifikan terhadap keputusan pemain dalam memilih judul game, namun memliki pengaruh signifikan terhadap pengujian usability game freemium.
\end{abstract}

Kata kunci: Tipe pemain, usability, freemium

\begin{abstract}
Games are the most popular category in the Play Store and App Store, the game industry has matured since decades ago from the age of the console. Value Chain games in the mobile age underwent significant changes, especially on the distribution channel side which cut many processes. However, unfortunately many developers only focus on the process of creating games, without preparing a good monetising strategy, one of which is the Freemium and Premium models. For this reason, further study is needed on the types of players that will relate to game purchasing decisions. This study aims to determine the correlation of player types with usability testing and can be used as a reference in determining the game business model for developers. The method used is descriptive analysis percentage. which is adjusted to the player's condition. The results of this study indicate that the type of player which consists of four types of players has no significant effect on the player's decision to choose the game title, but has a significant effect on the usability test of freemium games.
\end{abstract}

Keywords: Player type, usability, freemium

\section{PENDAHULUAN}

Game merupakan kategori terpopuler di Play Store dan App Store, matangnya industri game sudah terbentuk sejak puluhan tahun lalu dari zaman konsol. Value Chain game di zaman mobile mengalami perubahan yang signifikan, terutama di sisi distribution channel yang memotong banyak proses. Perubahan yang terjadi diakibatkan oleh platform digital yang memudahkan proses distribusi menjadi lebih mudah. Namun dibalik kemudahan itu, diperlukan adaptasi yang signifikan dalam proses produksi game.

Selain itu, platform Steam di PC (personal computer) juga memberikan kontribusi yang besar dalam proses penjualan game. Fenomena ini kemudian melahirkan developer indie yang 
masuk ke industri game untuk mendapatkan keuntungan. Akan tetapi, disayangkan banyak developer banyak hanya berfokus pada proses penciptaan game, tanpa mempersiapkan strategi monetising yang baik, salah satunya adalah model Freemium dan Premium.

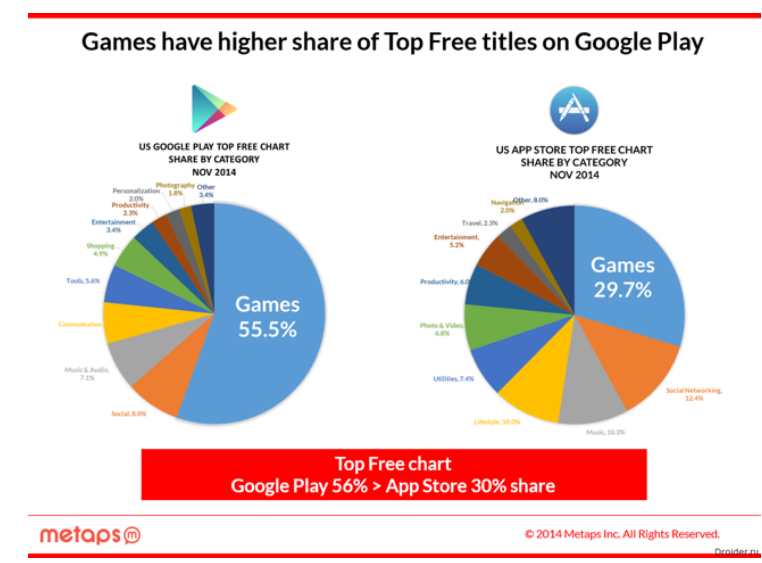

Gambar 1. Game menjadi kategori terpopuler di Google Play dan App Sore Tinggi

(Sumber: metaps.inc [1])

Gambar 1 menunjukkan bahwa tren saat ini game freemium lebih mendominasi pasar, untuk itu penelitian ini berfokus pada pengujian game freemium dengan model bisnis iklan dan in app purchase. Penelitian ini bertujuan untuk mengetahui korelasi tipe pemain terhadap pengujian usability game freemium, dan dapat digunakan sebagai salah satu acuan dalam penentuan model bisnis game bagi para developer.

Penelitian ini memiliki beberapa batasan sebagai berikut:

1. Lingkup. Penelitian ini hanya berfokus pada usability dan tipe pemain, tidak kepada proses pengembangan dan dampak game.

2. Platform. Penelitian yang dilakukan mengkaji game digital hanya pada OS Android, dan IOS.

3. Variable. Komponen variable yang digunakan hanya akan membahas tentang usability dan tipe pemain.

4. Model bisnis. Model bisnis yang akan diteliti hanyalah Freemium, sedangkan model bisnis lain tidak akan diteliti lebih dalam.

5. Populasi. Survei yang dilakukan hanya di lingkup Universitas AMIKOM Yogyakarta dengan asumsi mewakili seluruh kategori pemain game.

Berdasarkan latar belakang penelitian yang telah ditulis, peneliti mengangkat rumusan masalah sebagai berikut:

1. Apakah tipe pemain mempengaruhi faktor pemilihan judul game?

2. Apakah tipe pemain mempengaruhi pengujian usability game freemium?

Peneliti mencari korelasi antara tipe pemain terhadap pengukuran usabilitas yang berfokus pada game mobile. Peneliti melakukan pengukuran usability berfokus pada game mobile pada platform IOS dan Android dengan model bisnis Freemium. Peneliti menggunakan elemen Tipe Pemain yang terbagi menjadi 10 cluster untuk menemukan pengaruh pengukuran usability pada game. Peneliti menggunakan 5 variable pada penelitian, yaitu judul game, learnability, memorability, errors, dan satisfiction pada pengujian usability game. Peneliti mengadopsi model Neilsen sebagai kuesioner usability pada game, dan membandingkan pengaruhnya terhadap teori tipe pemain oleh Bartle taxonomy. Peneliti menggunakan Usability Kuesioner untuk mengukur game mobile dengan fokus pada model bisnis freemium.

Adapun peneliti pendahulu yang telah membahas tentang hal ini adalah berikut: Naser [2] mengukur usability pada website dengan menenkankan faktor Successful Task Completion, 
dan Mistake melakukan perbandingan kuesioner yang digunakan untuk mengukur usability pada website. Handiwidjojo [3] melakukan pengujian usability pada sistem informasi dengan menggunakan variable gender dan faktor pendidikan dalam menentukan pengaruh penelitian. Farahwahida [4] melakukan pengukuran usability berdasarkan demografi yang terdiri dari gender, usia, pay method, dan platfrom game.

Hookham [5] memadukan pengukuran usability dengan Perceived Usefulness dan Ease of Use pada Serious game dan traditional online program. menggunakan Standard Usability Problem List (SLUP) dan Software Usability for Blind Children Questionnaire (SUBC). untuk mengukur beberapa game multimodal dengan variable: Mode, feedback graphics dan audio. Wegner [6] menggunakan kuesioner dari MEC-SPQ Spatial Presence Questionnaire dan System Usability Scale (SUS) questionnaire yang telah dimodifikasi untuk game virtual reality. Sheila [7] menciptakan cardgame untuk proses pembelajaran mitigasi bencana gempabumi.

Peneltian-penelitian terdahulu memberikan pandangan baru kepada peneliti untuk melakukan sebuah penelitian baru, yaitu mencari korelasi pengujian usability terhadap tipe pemain dan mencari korelasi antara tipe pemain dengan pemilihan judul game freemium. Beberapa perbedaan yang mendasar dari penelitian terdahulu adalah pada penelitian ini, peneliti melakukan pengujian sebanyak dua kali, yaitu pengujian tipe pemain dan kemudian melakukan proses uji usability terhadap game freemium, hasil dari kedua pengujian tersebut kemudian dikorelasikan untuk menjawab rumusan masalah yang sudah ditentukan pada penelitian ini.

\subsection{Game freemium}

\section{METODE PENELITIAN}

Suatu model bisnis menggambarkan pemikiran tentang bagaimana sebuah organisasi menciptakan, memberikan, dan menangkap nilai-nilai baik itu ekonomi, sosial, ataupun bentukbentuk nilai lainnya. Istilah model bisnis, karena itu, dipakai untuk ruang lingkup luas dalam konteks formal dan informal untuk menunjukkan aspek inti suatu bisnis, termasuk mencakup maksud dan tujuan, apa-yang-ditawarkan, strategi, infrastruktur, struktur organisasi, praktikpraktik niaga, serta kebijakan-kebijaan dan proses-proses operasional. Game freemium lebih cepat dikembangkan dibandingkan dengan game berbayar, namun lebih banyak membutuhkan permission pada system Android dan fitur tambahan untuk proses monetizing [8]. Selain itu game berbayar yang menggunakan model tradisional cenderung lebih sedikit memiliki masalah, dibandingkan dengan model freemium yang harus menanamkan trik psikologi untuk mempertahankan pemain bermain lebih lama di dalam game [9].

Sejarah singkat mengenai model bisnis, mungkin berlangsung sebagai berikut. Yang paling dikenal dan paling dasar adalah model bisnis ala pemilik toko. Buka toko di lokasi di mana pelanggan potensial mungkin berada, lalu pajang produk dan jasa di sana. Selama bertahun-tahun, banyak model bisnis berkembang kian canggih. Model bisnis kail dan umpan (yang juga dirujuk sebagai "model bisnis gunting dan pisau cukur" atau "model bisnis produkproduk terikat") telah diperkenalkan pada awal abad ke-20. Model ini bekerja dengan menawarkan produk dasar di level harga yang rendah, seringnya dalam harga rugi (umpan), lalu mengenakan biaya untuk produk isi ulangnya, atau produk-produk dan layanan lain yang terkait. Contohnya ialah: gunting (umpan) dan pisau cukur (kail); ponsel (umpan) dan pulsa bicara (kail); printer (umpan) dan tinta isi ulang (kail); serta kamera (umpan) dan hasil fotonya (kail). Sebuah variasi menarik dari model ini adalah seorang pengembang peranti lunak yang memberikan peranti lunak pembaca dokumen secara gratis, tetapi mengenakan sejumlah biaya untuk peranti lunak penulis dokumennya

Pada tahun 1950-an, model bisnis baru telah muncul dari restoran McDonald dan perusahaan Toyota. Pada 1960-an, inovatornya ialah Wal-Mart dan Hypermarkets. Masa 1970an menyaksikan model bisnis baru dari FedEx dan Toys R Us; 1980-an dari Blockbuster, Home Depot, Intel, dan Dell Computer; 1990-an ada Southwest Airlines, Netflix, eBay, Amazon.com, dan Starbucks. Kurang dipikirkannya persoalan model bisnis ini telah juga menjadi masalah di era perusahaan dot-com. Kini, tipe model bisnis bergantung kepada bagaimana teknologi digunakan. Sebagai contoh, wirausahawan di dunia maya juga telah menciptakan model baru 
secara keseluruhan yang sepenuhnya bergantung kepada teknologi yang ada atau sedang berkembang. Dengan memanfaatkan teknologi, pebisnis dapat menjangkau pasar dalam jumlah besar tetapi dengan ongkos minimal. D.Fitton [10] menemukan bahwa game freemium memiliki keberagaram tinggi dalam proses monetising, hal ini mengakibatkan banyaknya developer yang tidak bijak dalam menerapkan mekanisme monetizing. Untuk itu peneliti membuat sebuah framework untuk mengevaluasi proses monetizing pada game freemium.

Freemium adalah sebuah model bisnis yang bekerja dengan menawarkan layanan mendasar secara cuma-cuma, dan mengenakan biaya premium hanya untuk fitur khusus atau lanjutan. Kata "freemium" merupakan gabungan lebur yang dibuat dengan mengombinasikan dua aspek dari model bisnis ini, yaitu "free" dan "premium". Model bisnis ini populer di kalangan perusahaan Web 2.0. Model game freemium yang sering dikenal dengan istilah Freeto-Play menjadi bahan kajian yang menarik, khususnya pada aspek kepuasan pemain. [11] melakukan pengujian user experience dengan menggunakan pengukuran psikologi untuk mengukur kepuasan pengguna.

\subsection{Tipe pemain}

Bartle taxonomy merumuskan empat tipe pemain yaitu achievers, explorers, socializers, dan killers. Adapun definisi tentang achievers adalah mereka yang bermain untuk mencapai sasaran-sasaran tertentu dan meningkatkan kemampuan mereka didalam game tersebut; sedangkan explorers adalah mereka yang suka menjelajah dan menyelidiki dunia permainan; Tipe pemain selanjutnya adalah socializers, yaitu mereka yang suka bersosialisasi dan berhubungan dengan para pemain lain dan tidak selalu dalam konteks permainan; Dan tipe yang terakhir adalah killers, pemain yang suka mengganggu atau menyakiti para pemain lain.

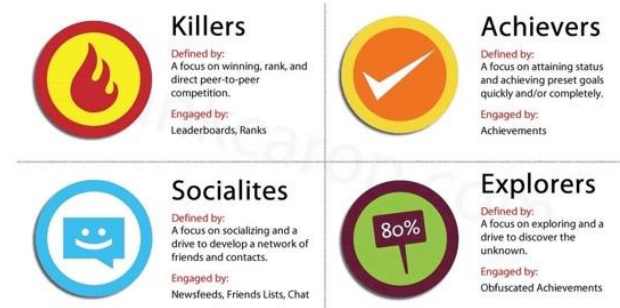

Gambar 2. Empat tipe pemain menurut Bartle

(Sumber: Bartle Taxonomy [12])

Penelitian tentang tipe pemain telah banyak dilakukan oleh peneliti, salah satunya adalah S Holm [13] dan G. Tondello [14] yang mengidentifikasi tentang apa, mengapa, dan bagaimana meningkatkan game berdasarkan tipe pemain. Hardcore gamer dan casual gamer memiliki perbedaan signifikan terhadap pandangan mengenai beberapa hal, salah satunya adalah mengenai ketersediaan tutorial di dalam game [15] dan adaptasi pemain [16]. Tipe pemain usia [17], dan gender [18] pada game multiplayer juga menentukan proses development dan balancing sebuah game ([19], M Cantallops mengatakan bahwa sebuah "event" pada sebuah game memberikan dampak yang berbeda pada respon pemain [20]. Salah satu aspek yang berpengaruh pada tipe pemain adalah kebiasaan player dalam mengakses game, pengukuran kebiasaan (behavior) ini dapat dilakukan dengan menggunakan Lag Sequential Analysis (LSA) [21] dan L Lacovides menemukan bahwa terdapat perbedaan signifikan dalam mengembangkan game single-player dengan cooperative [22]. Disisi lain, C Guckelsberger berhasil memprediksi Player Experience (PX) menggunakan Procedural Content Generation (PCG) [23]. Selain itu D.Ang juga berhasil mengembangakan sebuah game yang dilengkapi dengan system player oriented yang dapat secara otomatis menyesuaikan tingkat kesulitan game berdasarkan pemain [24].

\subsection{Usability Testing}

Uji kegunaan aplikasi smartphone terutama dilakukan oleh alat uji kegunaan yang paling umum dalam praktik pengembangan. Menurut Nielsen, Usability adalah analisa kualitatif 
yang menentukan seberapa mudah user menggunakan antarmuka suatu aplikasi. Suatu aplikasi disebut usable jika fungsi-fungsinya dapat dijalankan secara efektif, efisien, dan memuaskan. Efektivitas berhubungan dengan keberhasilan pengguna mencapai tujuan dalam menggunakan suatu perangkat lunak. Efisiensi berkenaan dengan kelancaran pengguna untuk mencapai tujuan tersebut. Kepuasan berkaitan dengan sikap penerimaan pengguna terhadap perangkat lunak. Pengujian usability dilakukan untuk mengevaluasi apakah sebuah aplikasi sudah sesuai dengan kebutuhan pengguna atau belum [25].

Usability menjadi faktor yang mempengaruhi sebuah aplikasi dapat dikatakan baik atau tidak. Menurut Neilsen usability sebagai atribut penilaian seberapa mudah aplikasi dapat digunakan. Perancangan antarmuka yang baik akan berdampak pada kemudahan dalam berinteraksi. Selain itu dapat meningkatkan nilai dari segi kepuasan pengguna.

Dasar dari penilaian usability adalah pengalaman yang dirasakan pengguna ketika menggunakan aplikasi tersebut. Berikut ini beberapa komponen kualitas menurut Nielsen:

1. Learnabilitas (Learnability), Mengukur kemudahan yang dapat dipelajari bahkan oleh pengguna pemula dalam menggunakan sebuah produk untuk pertama kali.

2. Efisiensi (Efficiency), Mengukur seberapa cepat pengguna dapat melakukan tugasnya setelah mempelajarai antarmukanya.

3. Memorabilitas (Memorability), Apakah aplikasi yang telah lama tidak digunakan ataupun aplikasi yang baru digunakan 1 kali dapat diingat oleh pengguna.

4. Kesalahan (Errors), Semakin kecil tingkat kesalahan maka semakin baik aplikasi tersebut. Aplikasi tersebut dapat dilihat dari berapa banyak kesalahan yang terjadi saat pengguna menggunakan aplikasi, sejauh mana akibat dari error tersebut, dan seberapa mudah seorang pengguna mengatasi kesalahan yang dilakukannya.

5. Kepuasan (Satisfaction), Kepuasan bersifat subjektif bagi masing-masing pengguna yang meliputi perasaan saat menggunakan aplikasi, pendapatnya tentang aplikasi tersebut dan lain-lain.

Regal melakukan pengujian usability terhadap media input ATM, peneliti menggunakan SEQ, UMUX dalam proses komparasi model input ATM [26]. Proses pengujian usability yang dilakukan oleh [27] melakukan perbandingan usability terhadap performa tiga aplikasi yang diujicobakan. Hal yang serupa juga dikerjakan oleh D Pearce yang membandingkan usability terhadap verifikasi sebuah software [28]. Komponen usability dapat dimodifikasi dengan cara pengajuan sebuah usability heuristics seperti yang dilakukan oleh J.Bowie pada pengujian software podcast [29]. Ada juga beberapa peneliti yang mengkorelasikan pengujian usability terhadap neuroanstomy terhadap pengujian aspek aesthetics.

\subsection{Alur penelitian}

Metode yang digunakan untuk mengetahui mengetahui korelasi tipe pemain terhadap pengujian usability pada game premium adalah deskriptif kuantitaif. Penelitian dimulai dengan proses pengumpulan data yang diambil dari populasi dengan teknik purposive sampling. Data yang didapatkan dari sample kemudian dianalisis secara deskriptif kuantitaif, dengan metode analisis tabulasi silang (crosstabs). Proses penelitian dapat dilihat pada gambar berikut: 


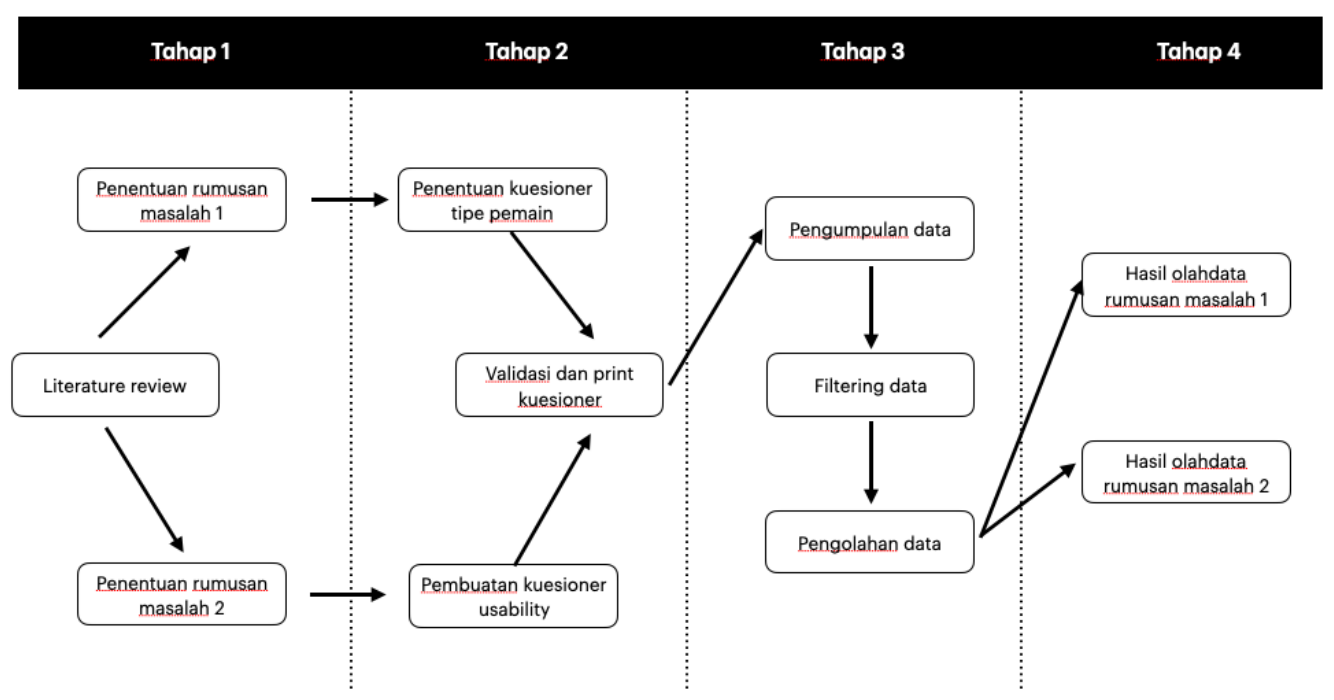

Gambar 3. Alur penelitian

Gambar 4 menjelaskan tentang alur penelitian yang terbagi menjadi empat tahapan. Tahapan pertama dimulai dengan proses literature review dari publikasi jurnal dan seminar, pada tahap ini juga dilakukan penentuan rumusan masalah pertama dan kedua yang akan diselesaikan pada penelitian ini. Tahap kedua dimulai dengan proses persiapan kuesioner yang akan dibagikan kepada responden, kuesioner ini terdiri dari dua bagian yang ditujukan untuk menjawab dua rumusan masalah. Pada tahap ini di akhiri dengan proses validasi kuesioner dan persiapan cetak kuesioner sebelum dibagikan kepada responden.

Proses entri data hasil pengambilan kuisioner dilakukan dengan cara mengkategorikan jenis pertanyaan sesuai dengan fungsi masing-masing dan kemudian mengolahnya. Proses analisis data dimulai dengan mengolah data menjadi sepuluh cluster berdasarkan tipe pemain. Hal ini dilakukan untuk mempermudah proses analisis data pada langkah berikutnya. Responden diminta untuk mengisi judul game yang pernah dimainkan, game yang ditulis hanya terbatas pada platform IOS dan Android dengan metode download gratis. Langkah selanjutnya adalah mengolah data sekunder terkait judul game yang dipilih oleh responden. Langkah selanjutnya adalah menganalisis fitur game yang dapat mewakili empat tipe pemain killer, socializers, achiever, dan exploler. Sedangkan Proses pengujian Usability dilakukan kepada seluruh responden terhadap game yang dipilih masing-masing. Skala pengukuran variabel dalam penelitian ini mengacu pada Skala Likert (Likert Scale), dimana masing-masing dibuat dengan menggunakan skala 1-4. Keseluruhan proses ini dilakukan pada tahap ke tiga pada alur penelitian.

Tahap ke 4 adalah tahap terakhir yang melaporkan hasil penelitian dan merepresentasika hasil tersebut dalam bentuk grafik. Hasil dari olahan data berupa derajad usability dari game mobile berdasarkan empat parameter, selain itu rekomendasi juga dituliskan sebagai salah satu cara untuk penyempurnaan penelitian ini. Hasil pertama ini digunakan untuk menjawab rumusan penelitian pertama Langkah terakhir dalam penelitian ini adalah mengukur besar pengaruh tipe game terhadap uji usability untuk menjawab rumusan masalah ke dua.

\subsection{Kuesioner}

Kuesioner terdiri dari dua bagian, bagian pertama adalah proses uji tipe pemain yang diperoleh dari website gartner, bagian kedua adalah pertanyaan yang berisi tentang usability yang meliputi

1. Learnabilitas (Learnability), Mengukur kemudahan yang dapat dipelajari bahkan oleh pengguna pemula dalam menggunakan sebuah produk untuk pertama kali. 
2. Efisiensi (Efficiency), Mengukur seberapa cepat pengguna dapat melakukan tugasnya setelah mempelajarai antarmukanya.

3. Memorabilitas (Memorability), Apakah aplikasi yang telah lama tidak digunakan ataupun aplikasi yang baru digunakan 1 kali dapat diingat oleh pengguna.

4. Kesalahan (Errors), Semakin kecil tingkat kesalahan maka semakin baik aplikasi tersebut. Aplikasi tersebut dapat dilihat dari berapa banyak kesalahan yang terjadi saat pengguna menggunakan aplikasi, sejauh mana akibat dari error tersebut, dan seberapa mudah seorang pengguna mengatasi kesalahan yang dilakukannya.

5. Kepuasan (Satisfaction), Kepuasan bersifat subjektif bagi masing-masing pengguna yang meliputi perasaan saat menggunakan aplikasi, pendapatnya tentang aplikasi tersebut dan lain-lain.

1.

Kuisioner dibagi dalam lima kelompok pertanyaan yang masing-masing seperti pada Tabel

\begin{tabular}{|c|c|c|}
\hline Pertanyaan & Variable & Kode \\
\hline $\begin{array}{l}\text { 1.Tulisan teks yang digunakan pada game mudah untuk } \\
\text { dibaca }\end{array}$ & Learnabilitas & L1 \\
\hline 2.Ikon-ikon yang ada cukup mudah untuk dipahami & Learnabilitas & L2 \\
\hline 3.Game mechanic mudah dimainkan & Memorabilitas & M1 \\
\hline 4.Tampilan menu dalam game mudah dikenali & Memorabilitas & M2 \\
\hline 5.Game sering mengalami lag/error & Errors & E1 \\
\hline 6.Saat munculnya iklan, game sering menjadi error & Errors & E2 \\
\hline $\begin{array}{l}\text { 7.Saya sering mendapat masalah saat melakukan } \\
\text { pembayaran di dalam game }\end{array}$ & Errors & E3 \\
\hline 8.Saya puas setelah membeli item berbayar di game. & Satisfaction & s1 \\
\hline 9.Menonton iklan lebih baik daripada membeli item & Satisfaction & S2 \\
\hline $\begin{array}{l}\text { 10.Saya lebih suka memainkan game gratis (dengan iklan } \\
\text { dan pembelian item) daripada membeli game premium }\end{array}$ & Satisfaction & S3 \\
\hline
\end{tabular}

Tabel 1 menunjukkan bahwa masing-masing pertanyaan mengacu pada komponen usability, masing-masing komponen diwakili oleh dua pertanyaan, kecuali komponen eror yang berisi tiga pertanyaan pada kuesioner. Seluruh soal kemudian diberikan kode khusus untuk mempermudah proses olah data pada tahap 3 di alur penelitian.

\subsection{Pengumpulan Data}

Penggunaan purposive sampling berdasarkan pertimbangan mendalam oleh peneliti, bahwa sampel benar-benar telah mewakili karakter populasi. Populasi dalam penelitian ini adalah seluruh civitas akademi Universitas AMIKOM yang merupakan pemain game, dalam hal ini diwakilkan oleh mahasiswa prodi Teknolgi Informasi semester 2 dan 4. Sampel yang diambil adalah sejumlah 144 orang. Teknik pengumpulan data dilakukan dalam bentuk pengisian kuesioner. Pertanyaan tertulis yang diberikan kepada pemain game berisi tentang tipe pemain dan pengukuran usability pada game yang dimainkan. Adapun data reponden dapat dilihat pada diagram berikut: 


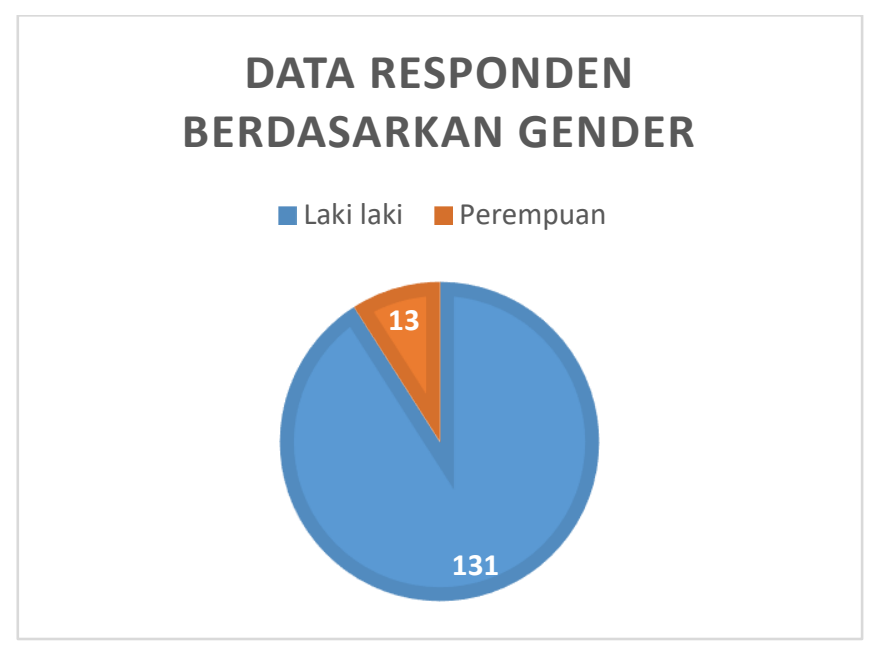

Gambar 4. Data responden berdasarkan gender

Gambar 5 menjelaskan bahwa jumlah responden laki-laki berjumlah 131 orang dan responden perempuan berjumlah 13 orang. Responden mengisi dua kuesioner yang terdiri dari kuesioner tipe pemain dan pengukuran usability. Pemilihan responden dikarenakan asumsi bahwa responden di prodi Teknologi informasi memiliki konsentrasi game, sehingga responden sudah memiliki pengetahuan dasar tentang game.

\subsection{Variabel Penelitian}

Variabel penelitian yang digunakan dalam penelitian ini yaitu (1) tipe pemain, (2) usability testing. Parameter yang digunakan untuk analisis yaitu usia, jenis kelamin, dan judul game. Usia digunakan untuk menganalisis tingkat pemahaman analisis game. Jenis kelamin digunakan sebagai pembanding tingkat kecendrungan untuk memilih judul game. dan judul game digunakan untuk mengetahui jenis genre game. Kelompok pertanyaan tersebut adalah sebagai berikut: 1) Mengukur apakah game mobile mudah dipelajari (Learnable) nilai dari variabel ini didapat dari rata-rata jawaban atas pertanyaan no 1-2. 2) Mengukur apakah fungsi dan fitur game mobile mudah diingat (Memorable) pada saat dimainkan. nilai dari variabel ini didapat dari rata-rata jawaban atas pertanyaan no 3-4. 3) Mengukur apakah pada suatu saat mobile game menunjukkan sejumlah kesalahan (Error) operasi yang tidak dikehendaki, nilai dari variabel ini didapat dari rata-rata jawaban atas pertanyaan no 5-7. 4) Mengukur game mobile nyaman untuk dioperasikan, dan mudah untuk diingat, nilai dari variabel ini didapat dari rata-rata jawaban atas pertanyaan no 8-10. 5) Mengetahui Judul game dan tipe pemain

\subsection{Metode Analisis}

Analisis tabulasi silang (crosstabs) adalah metode analisis yang paling sederhana tetapi memiliki daya menerangkan cukup kuat untuk menjelaskan hubungan antar variabel. Untuk itu ada beberapa prinsip sederhana yang perlu diperhatikan dalam menyusun tabel silang agar hubungan antara variabel tampak dengan jelas. Metode analisis ini digunakan untuk menguji korelasi antara variabel dalam tabel kontigensi sehingga diketahui apakah proporsi dari dua (2) peubah terjadi karena kebutuhan atau karena adanya asosiasi. Test ini cukup sederhana dan mudah dihitung dari hasil tabel silang. Dalam analisis tabel silang, peneliti menggunakan distribusi frekuensi pada sel-sel dalam tabel sebagai dasar untuk menyimpulkan hubungan antara variabel-variabel penelitian sehingga dengan demikian dapat dengan mudah melihat keterkaitan hubungan antara dua variabel.

\subsection{Cara Pengolahan Data}

Data yang digunakan adalah data primer dan sekunder, data primer yang dimaksud yaitu hasil dari pengisian kuesioner. Cara pengolahan data adalah upaya untuk mencapai tujuan penelitian dengan metode atau teknik tertentu. Data yang diperoleh kemudian diolah dengan 
menggunakan tabulasi silang. Adapun data primer yang dimaksuda adalah data tipe pemain, dan data pengukuran usabilitas. Sedangkan data sekunder adalah data tentang genre game dan fitur game premium pada game.

\subsection{Cara Analis Data}

Analisis data yang digunakan yaitu tabulasi silang (crosstabs). Proses analisis data dilakukan dalam empat tahap, yaitu Crosstabs tipe pemain berdasarkan learnability, efisiensi, errors, dan satisfaction. Data kuesioner diolah dengan cara mengclusterkan pemain berdasarkan game yang dipilih, kemudian menganalisis tipe pemain. Hal ini dilakukan untuk menjawab rumusan permasalahan yang pertama. Langkah selanjutnya adalah menganalisis korelasi tipe pemain terhadap pengaruh penilaian usability game per judul game. Langkah kedua ini dilakukan untuk menjawab rumusan permasalahan yang kedua.

Skala pengukuran variabel dalam penelitian ini mengacu pada Skala Likert (Likert Scale), dimana masing-masing dibuat dengan menggunakan skala 1-4. Proses analisis data dimulai dengan memberikan nilai 1-4 ke daftar penilaian Usability. Sangat setuju $=4$, Setuju $=$ 3 , Tidak Setuju $=2$, dan Sangat Tidak Setuju $=1$.

Nilai nilai tersebut kemudian dihitung dalam bentuk tabel tunggal melalui distribusi frekuensi dan persentase.dengan menggunakan formula sebagai berikut:

$\mathbf{P}=\mathbf{f} / \mathbf{N} \times 100 \%$

$\mathrm{P}:$ Persentase

f. : Frekuensi data

$\mathrm{N}$ : Jumlah sampel yang diolah

Hasil dari olahan data berupa derajad usability dari Tangible game dan aplikasi pendukung berdasarkan lima parameter, selain itu rekomendasi juga dituliskan sebagai salah satu cara untuk penyempurnaan penelitian ini.

\section{HASIL DAN PEMBAHASAN}

\subsection{Clustering data responden berdasarkan tipe pemain}

Peneliti melakukan pemeriksaan data, dalam tahap ini akan dilakukan pemeriksaan kuisoner untuk menentukan berapa jumlah data yang hilang dan berapa jumlah data yang isiannya tidak dapat digunakan karena salah pengisian data. Hasil kluster responden berdasarkan tipe pemain dapat di lihat pada gambar berikut:

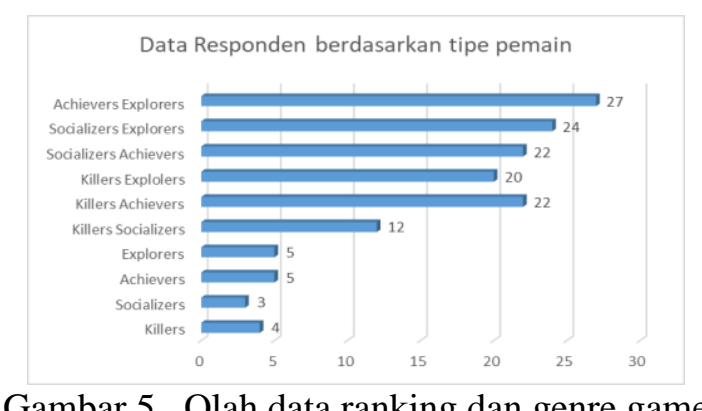

Gambar 5. Olah data ranking dan genre game

Gambar 6 menunjukkan bahwa tipe pemain dibagi menjadi dua bagian utama, yaitu bagian pemain dengan satu tipe dominan berjumlah empat tipe killer (4), socializers (3), achiever (5), dan exploler (5). Sedangkan bagian kedua adalah pemain dengan dua tipe dominan sebagai berikut Killers Socializers (12), Killers Achiever (22), Killers Exploler (20), Socializer Achiever (22), Socializer Exploler (24), Achiever Exploler (27). 


\subsection{Membuat ranking dan analisis genre dan fitur game} berikut:

Hasil dari rangking game dan anilisis genre serta fitur game dapat dilihat pada gambar

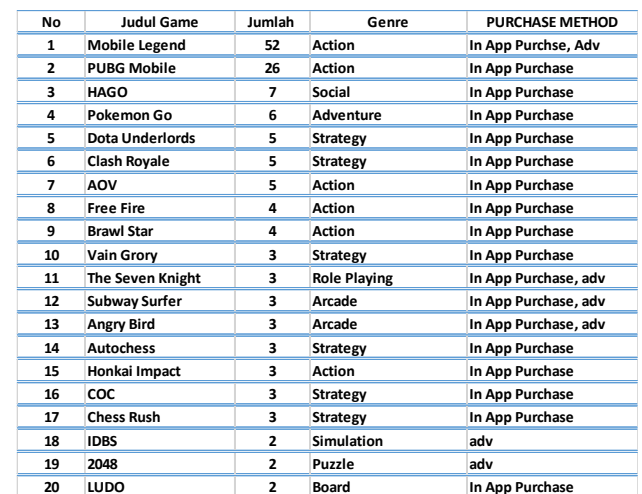

Gambar 6. Olah data ranking dan genre game

Hasil kuesioner yang diperoleh dari 144 responden menunjukkan bahwa 5 besar judul game yang dimainkan adalah judul game populer yang ada di Play store dan Apple Store. Dari data ini dapat dilihat bahwa sebagian besar game yang dipilih responden adalah game dengan genre Action (6), Arcade (2), Adventure (1), Strategy (6), Social (1), Role Playing (1), Simulation (1), Puzzle (1) dan Board (1). Data genre game diperoleh dengan mengklarifikasi judul game ke kategori game di playstore dan Apple Store.

Tabel 2. Analisis fitur game terhadap tipe pemain

\begin{tabular}{|c|c|c|c|c|c|}
\hline No & Judul Game & Leaderboard & Arena & Item berbayar & $\begin{array}{c}\text { Tambahan } \\
\text { Map/karakter } \\
\text { tambahan }\end{array}$ \\
\hline 1 & Mobile Legend & $\checkmark$ & $\checkmark$ & $\checkmark$ & $\checkmark$ \\
\hline 2 & PUBG Mobile & $\checkmark$ & $\checkmark$ & $\checkmark$ & - \\
\hline 3 & HAGO & $\checkmark$ & $\checkmark$ & $\checkmark$ & $\checkmark$ \\
\hline 4 & Pokemon Go & $\checkmark$ & - & $\checkmark$ & $\checkmark$ \\
\hline 5 & Dota Underlords & $\checkmark$ & $\checkmark$ & - & $\checkmark$ \\
\hline 6 & Clash Royale & $\checkmark$ & $\checkmark$ & $\checkmark$ & $\checkmark$ \\
\hline 7 & AOV & $\checkmark$ & $\checkmark$ & $\checkmark$ & $\checkmark$ \\
\hline 8 & Free Fire & $\checkmark$ & $\checkmark$ & $\checkmark$ & $\checkmark$ \\
\hline 9 & Brawl Star & $\checkmark$ & $\checkmark$ & $\checkmark$ & $\checkmark$ \\
\hline 10 & Vain Grory & $\checkmark$ & $\checkmark$ & $\checkmark$ & $\checkmark$ \\
\hline 11 & The SeVen Knight & $\checkmark$ & $\checkmark$ & $\checkmark$ & $\checkmark$ \\
\hline 12 & Subway Surfer & $\checkmark$ & $\checkmark$ & $\checkmark$ & $\checkmark$ \\
\hline 13 & Angry Bird & $\checkmark$ & - & $\checkmark$ & $\checkmark$ \\
\hline 14 & Autochess & $\checkmark$ & $\checkmark$ & $\checkmark$ & $\checkmark$ \\
\hline 15 & Honkai Impact & $\checkmark$ & $\checkmark$ & $\checkmark$ & $\checkmark$ \\
\hline 16 & COC & $\checkmark$ & $\checkmark$ & $\checkmark$ & $\checkmark$ \\
\hline 17 & Chess Rush & $\checkmark$ & $\checkmark$ & $\checkmark$ & $\checkmark$ \\
\hline 18 & IDBS & - & - & $\checkmark$ & - \\
\hline 19 & 2048 & $\checkmark$ & - & - & - \\
\hline 20 & LUDO & $\checkmark$ & $\checkmark$ & $\checkmark$ & - \\
\hline
\end{tabular}

\subsection{Pengujian Usability kepada sepuluh tipe pemain}

Hasil pengujian usabilility di skala likert disampaikan dalam bentuk table 3 .

Tabel 3. Nilai Rata Rata Kriteria Nielsen

\begin{tabular}{|c|l|c|c|c|c|c|c|}
\hline Kode tipe & \multicolumn{1}{|c|}{ Tipe Pemain } & $\begin{array}{c}\text { Jumlah } \\
\text { Responde } \\
n\end{array}$ & Learnabilitas & Memorabilitas & Errors & Satisfaction & $\begin{array}{c}\text { Rata- rata } \\
\text { Keseluruhan }\end{array}$ \\
\hline \hline 1 & Killers & 4 & 3.38 & 3.00 & 2.17 & 2.58 & 2.78 \\
\hline \hline 2 & Socializers & 3 & 3.17 & 3.17 & 2.11 & 2.67 & 2.78 \\
\hline \hline 3 & Achievers & 5 & 3.60 & 3.30 & 2.13 & 2.40 & 2.86 \\
\hline \hline 4 & Explorers & 5 & 3.30 & 3.20 & 2.33 & 2.27 & 2.78 \\
\hline \hline 5 & Killers Socializers & 12 & 3.50 & 3.33 & 2.17 & 1.75 & 2.69 \\
\hline \hline 6 & Killers Achievers & 22 & 3.41 & 3.32 & 2.23 & 1.77 & 2.68 \\
\hline \hline 7 & Killers Explolers & 20 & 3.30 & 3.23 & 2.07 & 1.95 & 2.64 \\
\hline \hline 8 & Socializers Achievers & 22 & 3.34 & 3.34 & 2.06 & 1.89 & 2.66 \\
\hline \hline 9 & Socializers Explorers & 24 & 3.48 & 3.46 & 2.07 & 2.06 & 2.77 \\
\hline \hline 10 & Achievers Explorers & 27 & 3.48 & 3.26 & 2.06 & 1.83 & 2.66 \\
\hline & Standar Deviasi & & 0.32 & 0.63 & 1.01 & 0.17 & \\
\hline & & & & & & & \\
\hline
\end{tabular}


Tabel 3 menunjukkan bahwa tingkat usability keseluruhan menunjukkan nilai diantara 2,64 sampai dengan 2,86 dari skala 1-4. Ini menunjukkan bahwa seluruh game yang diuji memiliki tingkat usabilitas baik (diatas standar deviasi) sehingga dapat dikatakan game mobile yang diuji sudah user friendly. Nilai terendah merujuk pada tipe pemain Killer Exploler dan nilai tertinggi diambil dari data tipe pemain 2,86. Langkah selanjutnya adalah menghitung selisih perbandingan penilaian berdasarkan tipe pemain yang dapat di lihat pada gambar berikut:

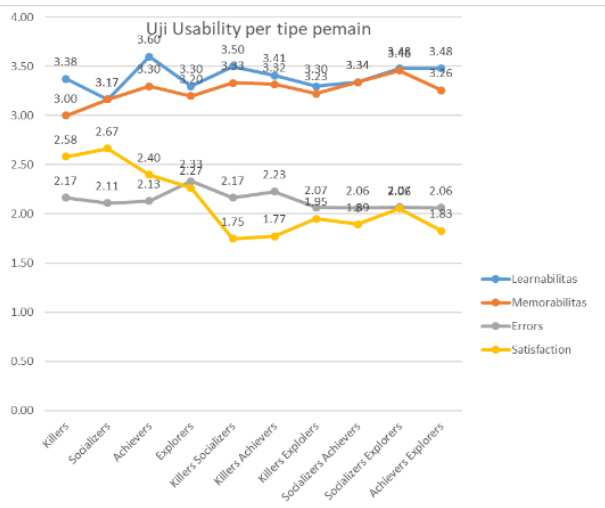

Gambar 7. Korelasi tipe pemain terhadap pengukuran usability

Gambar 8 menunjukkan bahwa terdapat beberapa pengaruh tipe pemain terhadap penilaian Usability, hal tersebut dapat dilihat dari garis yang naik turun. Garis ini mengidentifikasikan bahwa semakin datar garis maka korelasi tipe pemain terhadap variable tersebut tidak signifikan. Sedangkan pada garis yang naik turun dapat diartikan bahwa tipe pemain sangat berpengaruh pada proses uji usability game mobile. Tipe pemain killer cenderung menyukai fitur arena, di fitur ini pemain dimungkinkan untuk melakukan tanding melawan musuh yang tak terbatas. Berbeda dengan fitur leaderboard yang tepat diimplementasikan kepada tipe pemain Achiver yang dominan mengejar poin tertinggi di dalam game. Fitur selanjutnya adalah item berbayar yang ditujukan untuk tipe pemain Exploler yang lebih menyukai pengumpulan rare item di dalam game. Sedangkan fitur terakhir adalah adanya tambahan dan karakter baru di dalam game yang ditujukan untuk tipe pemain socializers yang lebih menyukai pembahasan game kepada rekan gamer lain.

\subsection{Pengukuran Pengaruh Tipe Pemain terhadap uji usability game}

Hasil dari pengukuran perngaruh tipe pemaian terhadap uji usability game disampaikan dalam bentuk gambar 9 .

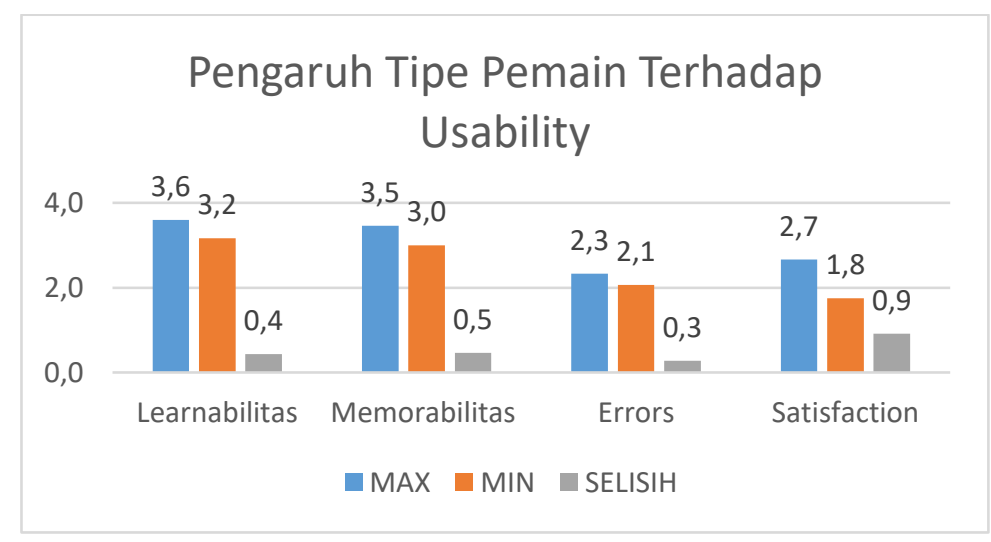

Gambar 8. Hasil pengukuran tipe pemain terhadap uji Usability 
Gambar 9 menjelaskan bahwa pengaruh tipe pemain terhadap Learnabilitas sebesar 0.4, hasil ini didapat dengan cara mengukur selisih batas atas dan batas bawah nilai usability per tipe pemain. Sedangkan pada Memorability selisih nilai yang didapat adalah 0.5. Dan pada Errors sebesar 0.3. Ketiga variable usability (Leanabilitas, Memorability, dan Errors) tidak terpanguh secara signifikan terhadap tipe pemain. Sedangkan variable satisfaction menunjukkan bahwa sangat terpengaruh terhadap tipe pemain. Hal ini terjadi karena masing-masing tipe pemain memiliki standar kepuasan tersendiri dalam menilai game.

\section{KESIMPULAN DAN SARAN}

Hasil dari penelitian terbagi menjadi dua kesimpulan yang menjawab dua rumusan permasalahan. Kesimpulan yang pertama adalah tipe pemain yang terdiri dari empat jenis pemain memiliki pengaruh yang tidak signifikan terhadap keputusan pemain dalam memilih judul game. Hal ini dibuktikan dengan gambar 8 yang menjelaskan bahwa pemilihan judul game yang dimainkan dipengaruhi oleh tren game yang sedang populer di Play store dan Apple Store. Hasil anailisis peneliti, hal ini dapat terjadi karena game freemium pada perangkat mobile saat ini memiliki fitur yang sudah dapat mengakomodir ke empat jenis pemain. Contoh dari fitur tersebut adalah adanya Leaderboard untuk tipe game, fitur chat dan arena untuk tipe pemain social, tambahan map dan item di dalam game untuk tipe pemain exploler, dan juga mode endless adventure untuk tipe pemain killer.

Hasil penelitian kedua adalah tipe pemain yang terdiri dari empat jenis pemain memiliki pengaruh yang signifikan terhadap pengujian usability game freemium. Hal ini dibuktikan dengan gambar 9 yang menjelaskan bahwa pengujuan usability sangat dipengaruhi oleh tipe pemain. Hasil analisis peneliti, hal ini dapat terjadi karena masing-masing tipe pemain memiliki kecendrungan yang berbeda, terutama pada variable satisfaction.

Saran peneliti untuk penelitian selanjutnya adalah peneliti selanjutnya dapat meneliti variable lain yang terkait dengan game, selain itu penelitian juga dapat dilakukan pada platfrom game lain seperti konsol dan game PC. Penelitian tentang kesiapan pemain dalam proses pembayaran juga menarik untuk diteliti sebagai penunjang utama model bisnis game freemium.

\section{DAFTAR PUSTAKA}

[1] Metaps, "Metaps Inc.” [Online]. Available: https://metaps.com/en/. [Accessed: 19-Mar2021].

[2] N. F. M. EL-firjani, E. K. Elberkawi, and A. M. Maatuk, "A Method for Website Usability Evaluation : A Comparative Analysis," Int. J. Web Semant. Technol., vol. 8, no. 3, pp. 01-11, 2017, doi: 10.5121/ijwest.2017.8301.

[3] W. Handiwidjojo and L. Ernawati, "Pengukuran Tingkat Ketergunaan ( Usability ) Sistem Informasi Keuangan Studi Kasus : Duta Wacana Internal Transaction ( Duwit )," Juisi, vol. 02, no. 01, pp. 49-55, 2016.

[4] F. Mohd, M. Noor, E. H. C. Daud, and S. S. Hasbullah, "Mobile games usability using the idea of mark overmars," ACM IMCOM 2016 Proc. 10th Int. Conf. Ubiquitous Inf. Manag. Commun., 2016, doi: 10.1145/2857546.2857578.

[5] G. Hookham, K. Nesbitt, and F. Kay-Lambkin, "Comparing usability and engagement between a serious game and a traditional online program," ACM Int. Conf. Proceeding Ser., vol. 01-05-Febr, 2016, doi: 10.1145/2843043.2843365.

[6] K. Wegner, S. Seele, H. Buhler, S. Misztal, R. Herpers, and J. Schild, "Comparison of two inventory design concepts in a collaborative virtual reality serious game," CHI Play 2017 Ext. Abstr. - Ext. Abstr. Publ. Annu. Symp. Comput. Interact. Play, pp. 323-329, 2017, doi: 10.1145/3130859.3131300.

[7] Rizky and S. L. G. Pudrianisa, "Pengujian Usability Pada Tangible Game Sebagai Media Promosi," Infos, vol. 2, no. 1, pp. 13-19, 2019.

[8] R. Saborido, F. Khomh, G. Antoniol, and Y. G. Gueheneuc, "Comprehension of Ads- 
Supported and Paid Android Applications: Are They Different?," IEEE Int. Conf. Progr. Compr., pp. 143-153, 2017, doi: 10.1109/ICPC.2017.25.

[9] K. K. Kimppa, O. I. Heimo, and J. T. Harviainen, "First dose is always freemium," ACM SIGCAS Comput. Soc., vol. 45, no. 3, pp. 132-137, 2016, doi: 10.1145/2874239.2874258.

[10] D. Fitton and J. C. Read, "Creating a framework to support the critical consideration of dark design aspects in free-to-play apps," Proc. 18th ACM Int. Conf. Interact. Des. Child. IDC 2019, pp. 407-418, 2019, doi: 10.1145/3311927.3323136.

[11] F. W. Petersen, L. E. Thomsen, P. Mirza-Babaei, and A. Drachen, "Evaluating the onboarding phase of free-to-play mobile games: A mixed-method approach," CHI Play 2017 - Proc. Annu. Symp. Comput. Interact. Play, pp. 377-388, 2017, doi: 10.1145/3116595.3125499.

[12] R. A. Bartle, "Step 4: Understand the Limits of Theory," Beyond game Des. nine steps Towar. Creat. better videogames, pp. 117-133, 2009.

[13] S. K. Holm, "Player types: What, why and how," CHI Play 2017 Ext. Abstr. - Ext. Abstr. Publ. Annu. Symp. Comput. Interact. Play, pp. 707-710, 2017, doi: $10.1145 / 3130859.3133220$.

[14] G. F. Tondello and L. E. Nacke, "Player characteristics and video game preferences," CHI Play 2019 - Proc. Annu. Symp. Comput. Interact. Play, pp. 365-378, 2019, doi: $10.1145 / 3311350.3347185$.

[15] R. Moirn, P. M. Léger, S. Senecal, M. C. B. Roberge, M. Lefebvre, and M. Fredette, "The effect of game tutorial: A comparison between casual and hardcore gamers," CHI Play 2016 - Proc. Annu. Symp. Comput. Interact. Play Companion, pp. 229-237, 2016, doi: $10.1145 / 2968120.2987730$.

[16] K. Rogers, C. Kamm, and M. Weber, "Towards Player-Centric Adaptivity,” pp. 269276, 2016, doi: 10.1145/2968120.2987725.

[17] M. V. Birk, M. A. Friehs, and R. L. Mandryk, "Age-based preferences and player experience: A crowdsourced cross-sectional study," CHI Play 2017 - Proc. Annu. Symp. Comput. Interact. Play, pp. 157-170, 2017, doi: 10.1145/3116595.3116608.

[18] K. Rogers, M. Aufheimer, M. Weber, and L. E. Nacke, "Exploring the role of non-player characters and gender in player identification," CHI Play 2018 - Proc. 2018 Annu. Symp. Comput. Interact. Play Companion Ext. Abstr., pp. 271-283, 2018, doi: 10.1145/3270316.3273041.

[19] J. Cechanowicz, C. Gutwin, S. Bateman, R. L. Mandryk, and I. Stavness, "Improving player balancing in racing games," CHI Play 2014 - Proc. 2014 Annu. Symp. Comput. Interact. Play, pp. 47-56, 2014, doi: 10.1145/2658537.2658701.

[20] M. M. Cantallops and M. A. Sicilia, "Motivations to read and learn in videogame lore: The case of League of Legends," ACM Int. Conf. Proceeding Ser., vol. 02-04-Nove, pp. 585-591, 2016, doi: 10.1145/3012430.3012578.

[21] G. Wallner, "Sequential analysis of player behavior," CHI Play 2015 - Proc. 2015 Annu. Symp. Comput. Interact. Play, pp. 349-358, 2015, doi: 10.1145/2793107.2793112.

[22] I. Iacovides, A. L. Cox, A. Avakian, and T. Knoll, "Player strategies: Achieving breakthroughs and progressing in single-player and cooperative games," CHI Play 2014 - Proc. 2014 Annu. Symp. Comput. Interact. Play, pp. 131-140, 2014, doi: 10.1145/2658537.2658697.

[23] C. Guckelsberger, C. Salge, J. Gow, and P. Cairns, "Predicting Player Experience without the Player.," Proc. Annu. Symp. Comput. Interact. Play - CHI Play '17, pp. 305-315, 2017.

[24] D. Ang and A. Mitchell, "Representation and frequency of player choice in playeroriented dynamic difficulty adjustment systems," CHI Play 2019 - Proc. Annu. Symp. Comput. Interact. Play, pp. 589-600, 2019, doi: 10.1145/3311350.3347165.

[25] A. Madan and S. K. Dubey, "Usability Evalution Methods: A Literature Review," Int. J. Eng. Sci. Technol., vol. 4, no. 02, pp. 590-599, 2012. 
[26] G. Regal, M. Busch, S. Deutsch, C. Hochleitner, M. Lugmayr, and M. Tscheligi, "Money on the move - Workload, usability and technology acceptance of second-screen ATM-interactions," MobileHCI 2013 - Proc. 15th Int. Conf. Human-Computer Interact. with Mob. Devices Serv., pp. 281-284, 2013, doi: 10.1145/2493190.2493211.

[27] C. P. Rohrer, J. Wendt, J. Sauro, F. Boyle, and S. Cole, "Practical usability rating by experts (PURE): A pragmatic approach for scoring product usability," Conf. Hum. Factors Comput. Syst. - Proc., vol. 07-12-May-, pp. 786-795, 2016, doi: $10.1145 / 2851581.2851607$.

[28] D. J. Pearce, "Some usability hypotheses for verification," PLATEAU 2015 - Proc. 6th Work. Eval. Usability Program. Lang. Tools, pp. 57-60, 2015, doi: $10.1145 / 2846680.2846691$.

[29] J. L. Bowie, "Sound Usability? Usability heuristics and guidelines for user-centered podcasts," Commun. Des. Q. Rev., vol. 13, no. 2, p. 15, 2012. 